\title{
SPATIOTEMPORAL EVOLUTION OF THE MARGINS OF LAKE UBERABA, PANTANAL FLOODPLAIN (BRAZIL)
}

\author{
Edward L. $L O^{1}$ \\ Aguinaldo SILVA2 \\ Ivan BERGIER ${ }^{3}$ \\ Michael M. MCGLUE ${ }^{1}$ \\ Beatriz Lima de Paula SILVA \\ Ana Paula Souza SILVA ${ }^{3}$ \\ Luciana Escalante PEREIRA ${ }^{2}$ \\ Hudson de Azevedo MACEDO ${ }^{4}$ \\ Mario Luis ASSINE ${ }^{4}$ \\ Edson Rodrigo dos Santos da SILVA2
}

\begin{abstract}
Aquatic macrophytes are important components of wetland ecosystems, and studying them contributes to a better understanding of ecological succession in the Pantanal. The function and history of floating macrophytes on the shores of Lake Uberaba, located on the Paraguay River floodplain, were examined. A multitemporal analysis of Landsat satellite images in the years 1984-2015 was conducted. For the analysis, a land cover map was generated with three classes: water, aquatic macrophytes, and surroundings (undefined vegetation). The results revealed $\sim 21.4 \%$ decrease in open water area of the lake over a period of 26 years $\left(-4.7 \mathrm{~km}^{2} / \mathrm{yr}\right.$. $)$. The expansion of vegetation helps explain the loss of open water and the recent shrinkage of Lake Uberaba. Macrophyte surface area along the lake margins grew by $1.4 \mathrm{~km}^{2} / \mathrm{yr}$. Through ecological succession, the growth and decay of aquatic plants ( $r$-strategists) along the lake shore likely provided the soil substrate needed for colonization by terrestrial plant assemblages ( $k$-strategists). This hypothesis that we propose to describe the evolution of dynamic geomorphological processes in Lake Uberaba should be tested in other areas to verify its applicability to similar systems.
\end{abstract}

Key words: Pantanal. Remote sensing. Ecological succession. Geomorphology. Aquatic macrophytes.

\footnotetext{
${ }^{1}$ Department of Earth and Environmental Sciences, University of Kentucky-UK. 101 Slone Research Bldg. Lexington, KY 40506-0053, USA. E-mails: \{edward.lo, michael.mcglue\}@uky.edu

${ }^{2}$ Laboratório de Estudos Socioambientais, Universidade Federal de Mato Grosso do Sul-Câmpus do Pantanal-Avenida Rio Branco, 1.270-CEP:79304-902-Corumbá, MS. E-mails: \{aguinald_silva, beatrizlpaula\}@yahoo.com.br; l.escalante.pereira@gmail.com; edson_r_silva@yahoo.com

${ }^{3}$ Laboratório de Conversão de Biomassa, Embrapa Pantanal. Rua 21 de Setembro, 1.880, Caixa postal 109-CEP:79320-900-Corumbá, MS. E-mails: ivan.bergier@embrapa.br; ana_psilva21@yahoo.com

${ }^{6}$ Laboratório de Estudo do Quaternário, Universidade Estadual Paulista. Av. 24A, 1515CEP:13506-900-Bela Vista-Rio Claro, SP. E-mails: hud_azevedo@hotmail.com; assine@rc.unesp.br
} 


\section{Resumo}

\section{Evolução espaço-temporal das margens do Lago Uberaba, planície do Pantanal (Brasil)}

As macrófitas aquáticas caracterizam-se como importantes componentes do ecossistema úmido e seu estudo contribui para compreender o processo de sucessão ecológica no Pantanal. Visando isto, o foco deste estudo foi determinar o papel das macrófitas aquáticas flutuantes nas margens do Lago Uberaba, localizado na planície fluvial do rio Paraguai. Através de análise multitemporal foram avaliados os anos entre 1984 a 2015, sendo utilizados para isto imagens da série de satélites Landsat. Para a análise, foi gerado o mapa de cobertura do solo com três classes: água, macrófitas aquáticas e entorno (vegetação indefinida). Os resultados revelaram decréscimo de $21,4 \%$ na lâmina de água do lago num período de 26 anos $\left(-4,7 \mathrm{~km}^{2} / \mathrm{ano}\right)$. A expansão da vegetação ajuda a explicar a redução na lâmina de água e consequente diminuição na área do lago. A cobertura de macrófitas no lago aumentou por 1,4 $\mathrm{km}^{2} / \mathrm{ano}$. $\mathrm{Na}$ sucessão ecológica, o crescimento e morte de plantas aquáticas ( $r$-estrategistas) nas margens do lago provavelmente colaborou para a formação do substrato de solo, então colonizado por plantas terrestres ( $k$-estrategistas). Esta hipótese que formulamos para descrever a evolução de processos geomorfológicos dinâmicos no Lago Uberaba deve ser testada em outras áreas para verificar sua aplicabilidade em sistemas similares.

Palavras-chave: Pantanal. Sensoriamento remoto. Sucessão ecológica. Geomorfologia. Macrófitas aquáticas.

\section{INTRODUCTION}

Floodplain lakes are the second most common type of lake in the world and are particularly abundant in association with the large tropical rivers of central South America (COHEN et al., 2015, p.2). Few studies have been conducted about the extant lakes on the Pantanal floodplain, which originates from Andean tectonics (COHEN et al., 2015, p.10). Regional (e.g., Andean mountain building) and local tectonic activity influence the formation of numerous lakes in the Pantanal basin (MCGLUE et al., 2015, p.56). These water bodies are often shallow and ephemeral over geologic time (COHEN, 2003, p.42). Several factors can influence the characteristics and longevity of floodplain lakes. Erosional and sedimentary processes from fluvial systems may isolate and create the accommodation necessary to form lake basins. By contrast, river-derived sediments may also fill floodplain lakes over very short timescales (10 $\left.10^{1}-10^{4} \mathrm{yrs}\right)$.

In terms of hydrology and geomorphology, measuring the extent of aquatic macrophyte surface area can indicate the stage of ecological succession and longevity of oxbow lakes and other floodplain lakes. The water hyacinth Eichhornia crassipes is one of the most abundant aquatic macrophytes that compose camalotes (floating islands lacking soil development) in the Pantanal wetlands (CASTRO et al., 2010, p.1; PIVARI et al., 2008, p.564; POTT; SILVA, 2015, p.121). It is particularly effective at producing organic material (i.e., histosols) that becomes a substrate for other vegetation to grow (e.g., ANDERSON, 2014, p.373). This species can be considered a pioneer in ecological succession, which is fundamental to the development of the varied Pantanal biomes.

In the Pantanal, ecological succession can be triggered by avulsive processes described by Assine et al. (2015a, p.107) (2015b, p.479) that cause flooding across vast plains, which may be occupied by aquatic, semi-aquatic, and terrestrial macrophytes. However, other more complex relations exist depending on factors such as connection between floodplain and main river channel, nutrient exchange, and the amount of sediments exported or stored (e.g., WARD et al., 1999, p.125; AMOROS and BORNETTE, 2002, p.762; HEILER et al., 1995, p.352). 
In a succession originating from avulsions, the landscape and the composition of its plants change over time, from flora composed predominantly of $r$-strategists (i.e., species that invest energy in reproduction, marked by short life cycles), to more terrestrial vegetation (e.g., grassy and woody vegetation) dominated by $k$-strategist species (i.e., species that invest energy in biomass fixation, characterized by long life cycles) (Figure 1 ). The $r$-strategist plants reproduce rapidly, whereas $k$-strategist plants allocate resources to growth, resulting in increased longevity and size of the individuals (GADGIL; SOLBRIG, 1972, p.14).

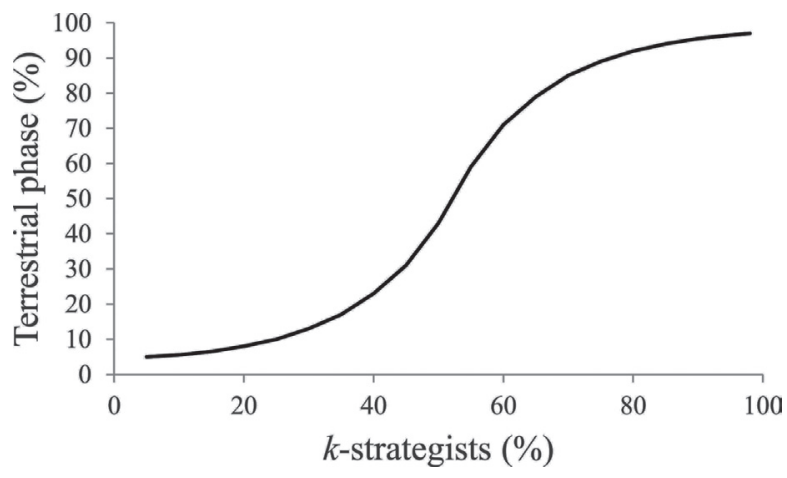

Figure 1 - In this conceptual model, the dominance of $k$-strategist plants relative to $r$-strategists over time in lacustrine areas of alluvial plains were expressed as a function of sediment and organic matter accumulation. The $k$-strategist plants have a greater chance of success as accumulated sediment and organic matter increasingly favor the terrestrial phase

Geotechnology is an important mechanism to analyze environmental change due to ecological succession. The use of geotechnology such as remote sensing, image processing, and geographic information systems (GIS) helps with monitoring and identifying environmental changes in riverine ecosystems (e.g., GALO et al., 2002, p.9). Not surprisingly, remote sensing is an approach widely used in various fields of Pantanal research, since many areas of the wetlands are undeveloped and difficult to access (COPATTI et al., 2015, p. 39; PALÁCIOS et al., 2016, p. 29; AYACH et al., 2014, p. 140; ALMEIDA et al., 2003, p. 85).

Souza et al. (2011, p.2038) used images from the Thematic Mapper (TM) sensor on the LANDSAT-5 satellite to map aquatic macrophytes in the Paraguay-Corixo Grande sub-region (ASSINE; SOARES, 2004, p.25) over two decades. This research revealed a positive correlation between the annual arrival of flood waters and the quantity of aquatic macrophytes and identified $70 \mathrm{~km}^{2}$ of permanent aquatic macrophytes in the Paraguay River floodplain. Permanent macrophyte areas are a reliable source of biomass energy (SOUZA et al., 2011, p.2041).

The objective of this study was to evaluate how the hydrogeomorphology of free-floating aquatic macrophytes affects the evolution of the Lake Uberaba fluviallacustrine system. Over time, we hypothesize that the successive accumulation of senescent remains of $r$-strategist aquatic macrophytes after each annual flood pulse can cause a nearly complete closure of the lake's open water area, leading to sedimentation and terrestrialization with predominantly $k$-strategist terrestrial macrophytes. This type of analysis has important implications for ecohydrology, a 
concept that relates ecology and hydrology in the interpretation of geomorphic processes (MORAES, 2009, p.677).

\section{MATERIALS AND METHODS}

Lake Uberaba (Figure 2) is situated near Morraria Ínsua in the southern part of the Pantanal of Cáceres sub-region. It lies on the fringes of the Paraguay River fluvial megafan, on the border between Brazil and Bolivia (ASSINE; SILVA, 2009, p.190). A fluvial megafan is a large $\left(\geq 10^{3} \mathrm{~km}^{2}\right)$ system of distributary rivers subject to seasonally elevated discharge (LEIER et al., 2005, p.289; ASSINE and SILVA, 2009, p.193; WEISSMANN et al., 2010, p.41; LATRUBESSE, 2015, p.2). Lake Uberaba is unique in the Pantanal for being influenced by multiple active channels, such as Corixo Grande and the recent Canzi River, identified by Assine et al. (2015a, p.100) (2015b, p.483). The lake is situated in a strategic location for studying the distal toe of a tropical fluvial megafan and primarily drains through Canal Dom Pedro II to Lake Gaíva. No information in the published literature is currently available about the hydrosedimentology and geological evolution of Lake Uberaba. The present elevation map was created based on updated 1 arc-second SRTM (Shuttle Radar Topography Mission) with 30-m spatial resolution (Figure 2).

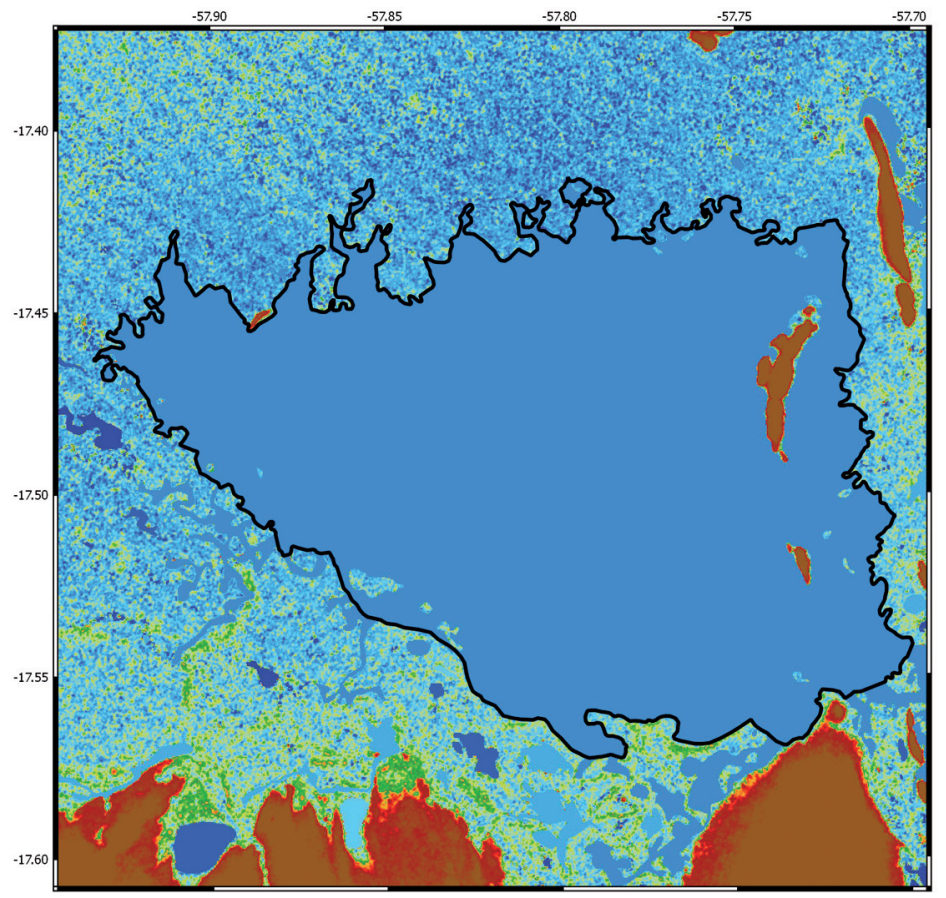

\section{Lake Uberaba}
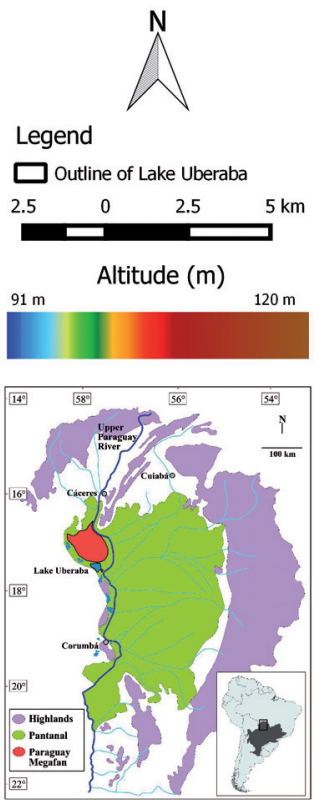

Figure 2 - Digital elevation map of the terrain at Lake Uberaba (outlined). The southern and eastern margins contain higher relief, which is rare in the Pantanal floodplain. The northern and western margins connect to the floodplain and much of the Paraguay River megafan 
This study was based on a 30-year historic series of satellite images (19842015) to map and quantify areas of open water and floating macrophytes in the lake vicinity. Landsat satellite images were processed in GIS for temporal analysis. The Landsat program is a series of environmental satellites developed by the United States for terrestrial observations and monitoring (WOODCOCK et al., 2008, p.1011). The first satellite of the program was launched in the 1970s, and the earliest satellite images were taken in 1972.

Of the series of satellites, images were used from Landsat-5, Landsat-7, and Landsat-8. Landsat-5 images from 1984 to 2011 were used except for the years 1999 and 2002 when Landsat-7 images provided better image quality. For the period 20132015, images from Landsat-8 were examined. Suitable images were not available for 2012 because Landsat-5 was decommissioned in 2011, the scan line corrector was not operational on Landsat-7, and Landsat-8 was not launched until 2013. Since the images underwent a classification procedure, comparisons among the images from different satellites (Table 1; PEREIRA et al., 2017, in press) were possible because spectral analysis was not needed. To map the annual open water surface area of the lake, images from the least rainy periods (decreased cloudiness) in the Pantanal dry season between 7 July and 19 October (Table 2) were obtained (path 227, row 72), georeferenced, and corrected from the USGS Global Visualization Viewer (GLOVIS, http://glovis.usgs.gov/) catalog.

The images were processed in the open source GIS programs SPRING version 5.3 and QGIS version 2.8. False color composites were assembled (RGB-543 in Landsat5 and Landsat-7; RGB-654 in Landsat-8). To generate a land cover map, supervised classification-based segmentation was applied to divide the images into regions (objects), resulting in supervised classification oriented to object. Supervised classification was accomplished in SPRING to map three thematic classes: water, aquatic macrophytes, and surroundings (undefined vegetation). With this classification, the land cover of each class could be estimated.

\section{Table 1 - characteristics of the satellites that captured all images used in this study}

\begin{tabular}{llcccl}
\hline Satellite & Sensor & $\begin{array}{c}\text { Spatial } \\
\text { Resolution } \\
(\mathrm{m})\end{array}$ & $\begin{array}{c}\text { Radiometric } \\
\text { Resolution } \\
(\mathrm{m})\end{array}$ & $\begin{array}{c}\text { NIR interval } \\
(\mu \mathrm{m})\end{array}$ & Status \\
\hline Landsat-5 & TM & $30 \mathrm{~m}$ & $8 \mathrm{~m}$ & $0.76-0.90$ & inactive \\
Landsat-7 & ETM+ L1T & $30 \mathrm{~m}$ & $8 \mathrm{~m}$ & $0.76-0.90$ & inactive \\
Landsat-8 & OLI_TIRS & $30 \mathrm{~m}$ & $16 \mathrm{~m}$ & $0.845-0.885$ & active \\
\hline (PEREIRA et al., 2017, in press) & & &
\end{tabular}

The Brazilian Navy provided Paraguay River stage height data measured at Cáceres, state of Mato Grosso (MT). These data were processed to obtain a historic series of annual flood peaks. This was similar to the historic series presented by Bergier and Resende (2010, p.39), who compared the Pantanal summer rainfall with the flood peak measured at the gauge station in Ladário, state of Mato Grosso do Sul (MS). 
Table 2 - Images used in this study were chosen from the USGS GLOVIS catalog based on dates with minimum cloud cover during the dry season

\begin{tabular}{cccccc}
\hline Satellite & Date & Satellite & Date & Satellite & Date \\
\hline Landsat-5 & $07 / 07 / 1984$ & Landsat-5 & $07 / 08 / 1995$ & Landsat-5 & 06/09/2006 \\
Landsat-5 & $27 / 08 / 1985$ & Landsat-5 & $25 / 08 / 1996$ & Landsat-5 & 24/08/2007 \\
Landsat-5 & $15 / 09 / 1986$ & Landsat-5 & $15 / 10 / 1997$ & Landsat-5 & $11 / 09 / 2008$ \\
Landsat-5 & $01 / 08 / 1987$ & Landsat-5 & $02 / 10 / 1998$ & Landsat-5 & 29/08/2009 \\
Landsat-5 & $06 / 10 / 1988$ & Landsat-7 & $27 / 09 / 1999$ & Landsat-5 & $19 / 10 / 2010$ \\
Landsat-5 & $07 / 09 / 1989$ & Landsat-5 & $07 / 10 / 2000$ & Landsat-5 & 06/10/2011 \\
Landsat-5 & $09 / 08 / 1990$ & Landsat-5 & $08 / 09 / 2001$ & Landsat-8 & 25/09/2013 \\
Landsat-5 & $15 / 10 / 1991$ & Landsat-7 & $03 / 09 / 2002$ & Landsat-8 & 27/08/2014 \\
Landsat-5 & $29 / 07 / 1992$ & Landsat-5 & $29 / 08 / 2003$ & Landsat-8 & $15 / 09 / 2015$ \\
Landsat-5 & $04 / 10 / 1993$ & Landsat-5 & $31 / 08 / 2004$ & & \\
Landsat-5 & $19 / 07 / 1994$ & Landsat-5 & $02 / 08 / 2005$ & & \\
\hline
\end{tabular}

In addition, fieldwork was conducted in September 2015 to verify the type of terrestrial vegetation at select sites. This work mainly consisted of taking photos of the shoreline vegetation, and making observations of the soil substrate along the varied shores. The vegetation analysis in satellite images was done based on pixel color. Therefore, fieldwork served to verify and minimize potential errors in supervised classification, helping distinguish between aquatic macrophytes and undefined vegetation.

Fieldwork was also an opportunity to conduct a bathymetric survey using a Furuno model GP-1650WF (200 kHz) echo sounder. A depth sounding was collected every $2 \mathrm{~m}$ along transects that spanned the lake. These depth data were interpolated by kriging (TopoToRaster) in ArcGIS 10 and manual contouring in Adobe Illustrator CS6 to generate the final bathymetric map.

\section{RESULTS AND DISCUSSION}

The evidence obtained from this study indicates that the open water area of Lake Uberaba decreased $\sim 21.4 \%$ over a period of 26 years (1985-2011), accompanied by increased aquatic macrophyte surface area (Figure 3, Table 3). However, the advance of the macrophyte coverage in the lake occurred independent of precipitation variability and fluvial discharge. This finding was based on the Cáceres, MT river level, which was considered a proxy for some of the lake inflows.

Figure 4 presents the results obtained from Landsat image analysis and from Paraguay River flood peaks at the Cáceres gauge station. In Figure 4C, we interpret that the macrophyte surface area will surpass $60 \%$ in the following decades. Considering that the largest part of this advancement was due to baceiros of Cyperaceae (floating islands with organic soil), the reduction in open water can represent an effect of ecological succession from $r$-strategist to $k$-strategist vegetation in these hydrologically 
dynamic environments as a function of avulsive processes (ASSINE et al., 2015a, p.87; PIVARI et al., 2008, p.564).

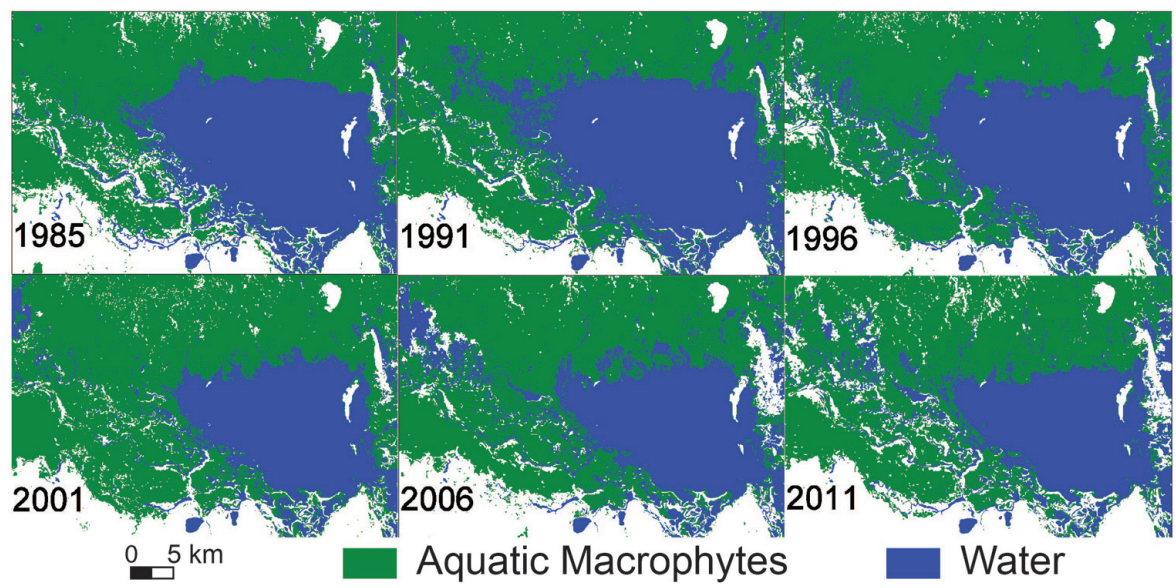

Figure 3 - Macrophytes (green) and water (blue) at the study site are featured in this abbreviated series of images. The area of open water reduced from $463 \mathrm{~km}^{2}(1985)$ to $364 \mathrm{~km}^{2}$ (2011), which represents

$\sim 21.4 \%$ loss. A large growth of aquatic macrophytes occurred in the northern part of the lake. Aquatic plants spectrally classified as terrestrial or surrounding areas (in white) also increased from 1985 to 2011

Table 3 - Numerical comparison of open water to macrophyte surface area shows an overall trend of decreasing open water area. Note that in 1985 and 2011, the Paraguay River stage at Cáceres, MT, Brazil was similar, which allows us to directly compare the land cover maps from those years

\begin{tabular}{cccc}
\hline Year & $\begin{array}{c}\text { Open water } \\
\text { area }\left(\mathrm{km}^{2}\right)\end{array}$ & $\begin{array}{c}\text { Macrophyte surface } \\
\text { area }\left(\mathrm{km}^{2}\right)\end{array}$ & $\begin{array}{c}\text { Paraguay R. } \\
\text { stage }(\mathrm{cm})\end{array}$ \\
\hline 1985 & 463 & 567 & 543 \\
1991 & 504 & 572 & 565 \\
1996 & 463 & 602 & 506 \\
2001 & 343 & 738 & 463 \\
2006 & 396 & 643 & 538 \\
2011 & 364 & 644 & 540 \\
\hline
\end{tabular}

The annual flood peak at Cáceres varied from 434 to $615 \mathrm{~cm}$, with a slight increase in the amplitude of the flood wave towards 2015 (Figure 4A). The annual flood peak at Cáceres correlated weakly with the total surface area of the lake $(r=$ $0.142 ; p=0.445)$. On the other hand, the total area of the lake diminished at an annual rate of $3.33 \mathrm{~km}^{2} / \mathrm{yr}$ (Figure 4B). The area of open water varied between 317 $\mathrm{km}^{2}$ and $642 \mathrm{~km}^{2}$, with a linearly decreasing rate of $4.7 \mathrm{~km}^{2} / \mathrm{yr}_{\text {., }}$, whereas the area of aquatic macrophytes varied between $405 \mathrm{~km}^{2}$ and $772 \mathrm{~km}^{2}$, with a linearly increasing rate of $1.4 \mathrm{~km}^{2} / \mathrm{yr}$. 


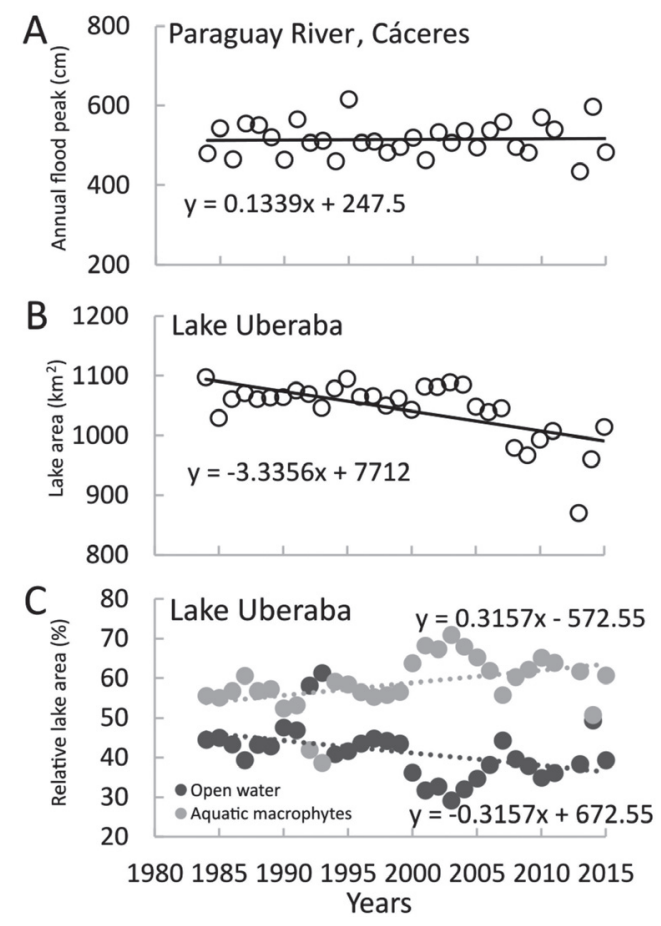

Figure 4 - Comparison of variations in hydrologic indicators in the interval 1984-2015: (A) level of the Paraguay River at Cáceres, MT (river stage, in centimeters) upstream of Lake Uberaba; (B) open water area in Lake Uberaba; (C) relative areas of open water and aquatic macrophytes in Lake Uberaba

The lake is shallow (Figure 5), with progressive change in depth due to low slope along the Paraguay River megafan. This feature allows for macrophyte colonization in regions with sufficient light reaching the lake bottom (1.4-2.1 m), mainly along the northern margins. The shape of the depth contours suggests the presence of paleochannels oriented in a NE-SW direction, indicating the existence of a subaerial floodplain prior to lake inception. However, active processes such as Canzi River inflow from the eastern margins likely continue to shape the bathymetry.

During fieldwork in September 2015, baceiros were identified as floating masses of aquatic macrophytes (Figure 6A), predominantly with grasses of the Cyperaceae family such as Scirpus sp. (Figure 6B) and water hyacinths (Figure 6C) on the northern margin of Lake Uberaba. Masses of camalote primarily composed of water hyacinths were observed near the lake's largest island (Morro do Pato), in the northeast (Figure 2) (PIVARI et al., 2008, p.564). 


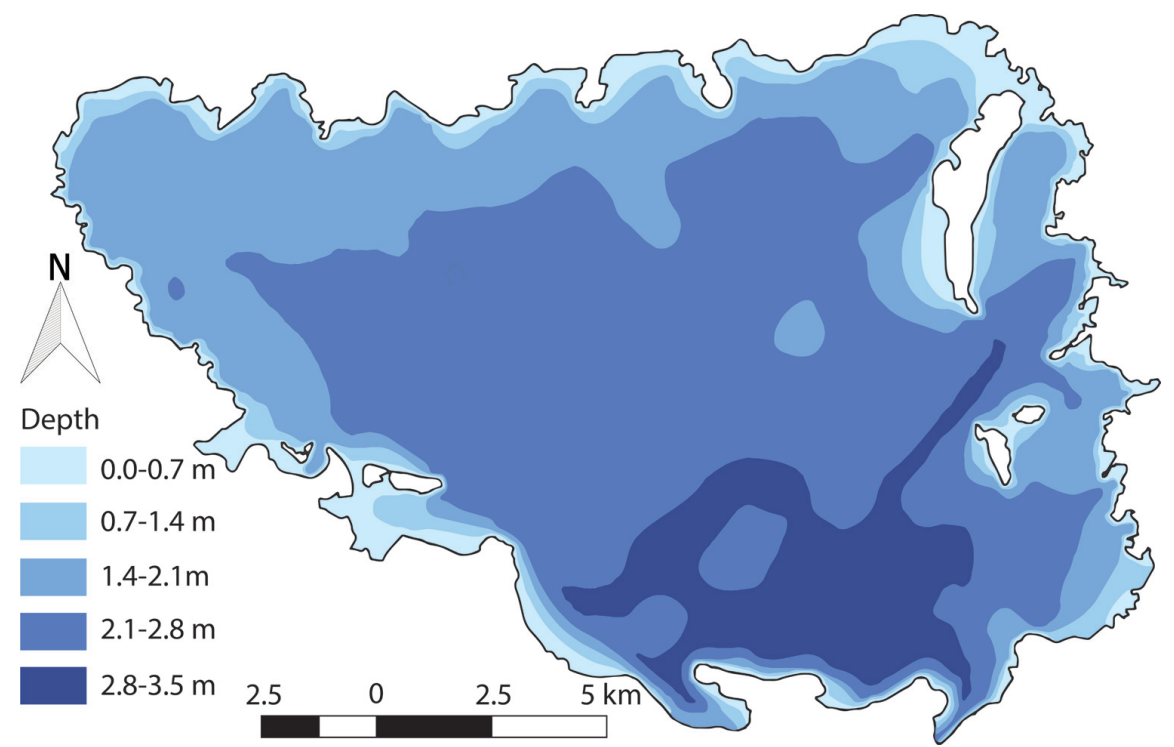

Figure 5 - Bathymetric map of Lake Uberaba in September 2015, showing the low slope of the lake bottom. Depth increases towards the south

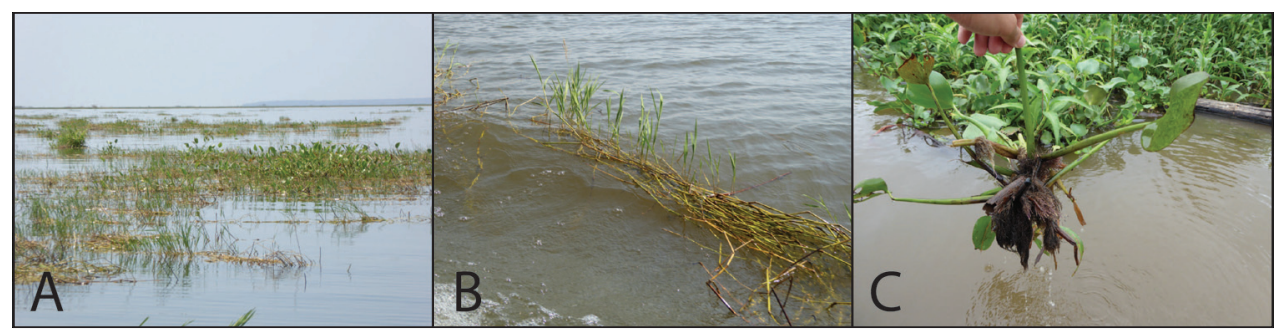

Figure 6 - Field photos of baceiros in different phenological stages (A) on the northern margin of Lake Uberaba $\left(17.46^{\circ} \mathrm{S} 57.86^{\circ} \mathrm{W}\right)$ on 3 Sept 2015. The vegetation was dominated by Cyperaceae (B) and water hyacinths (C)

Photo credit: Edward Lo

The Landsat image analysis revealed the presence of areas influenced by suspended sediment, which was confirmed in the field. Although the date of the image (15 Sept 2015) and the date of the fieldwork (3 Sept 2015) were not the same, the suspended sediments was the most appropriate interpretation to explain the visible, light-colored eddies in Lake Uberaba satellite images (Figure 7). We suspect a change in mixing intensity likely occurred between these two dates, but the main factor behind eddy visibility was suspended sediment with higher reflectivity (e.g. CAI et al., 2015, p.300; MIN et al., 2012, p.387). 


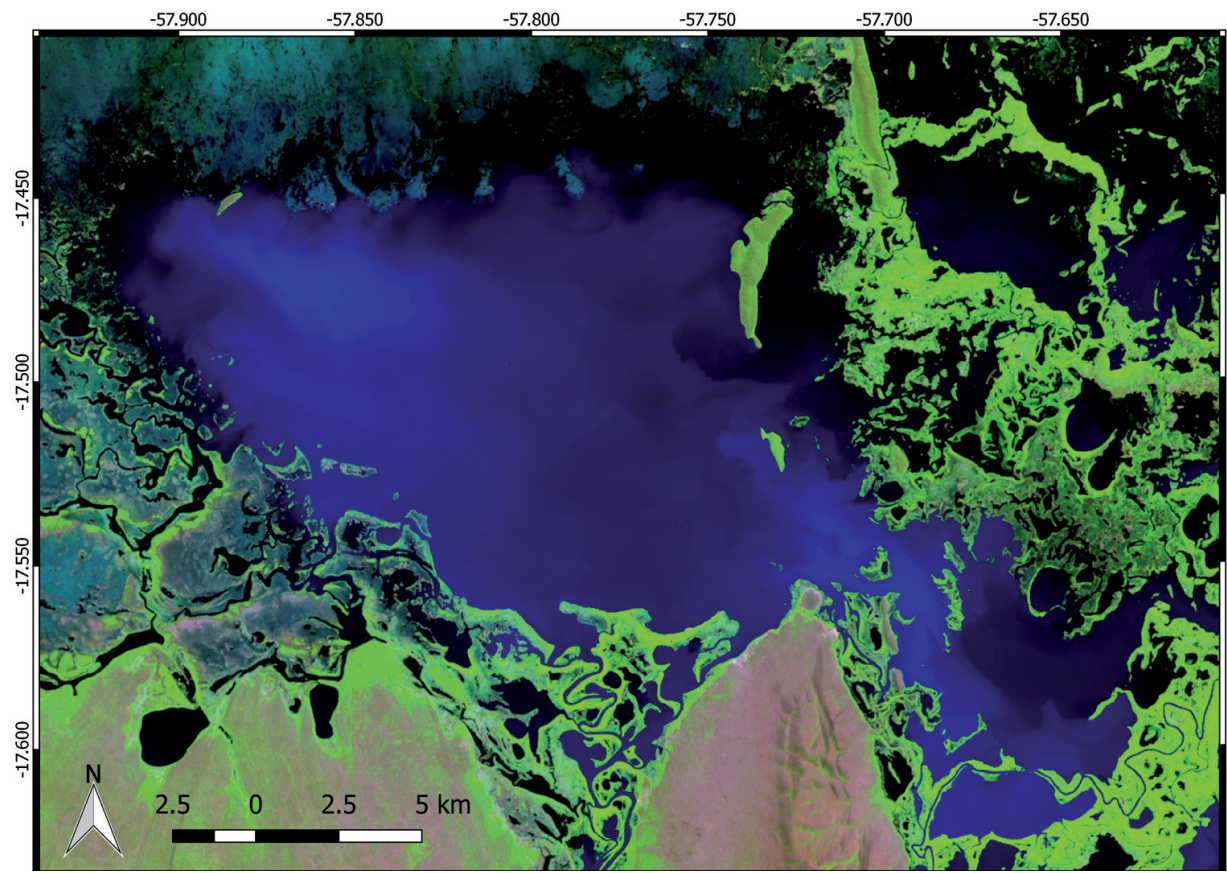

Figure 7 - In this Landsat-8 image from 15 September 2015 (false color RGB-654), eddies and billows are visible in the water column of Lake Uberaba. We interpret the lighter hues of blue as greater suspended sediment concentration

Figure 8 presents a conceptual model of ecological succession in fluvial megafan lakes with avulsive processes. Initially, colonization is accomplished by camalotes of water hyacinths including Eicchornia sp., Salvinia sp., and other species (CASTRO et al., 2010, p.2). As these plants develop, some break away and float freely in the form of smaller camalotes, and others perish onsite (CASTRO et al., 2010, p.2). Species of Cyperaceae are also part of the initial colonization process. These r-strategist plants, however, tend to form baceiros, which are larger, more aggregated banks of floating plants that tend to build up in successive layers as each generation dies. This successive process leads to the formation of histosols (Figure 9, see PIVARI et al., 2008, p. 565).

Live plants are as important for sediment retention as plant remains, increasing the capacity for histosols to sustain brushy and arboreal species (POTT; SILVA, 2015, p.122). The growth of brushy and arboreal species can transform a system to a new level of succession at the semi-terrestrial or purely terrestrial phase. Despite continued influence from the annual flood pulse, the successional climax gives way to woody vegetation, thereby transforming an environment preferentially aquatic to a preferentially terrestrial one (Figure 8 ). This process may be one of the ways that forested islands and corridors form in floodplains. The northern margins of Lake Uberaba are dominated by floating aquatic grasses of the Cyperaceae family, which suggests that this region is already in the second and third phases of ecological succession as seen in Figure 8. Lake Uberaba's southeastern margins (Figure 2) have terrestrial vegetation that can result in an aquatic-terrestrial ecological succession process originating from avulsion. 


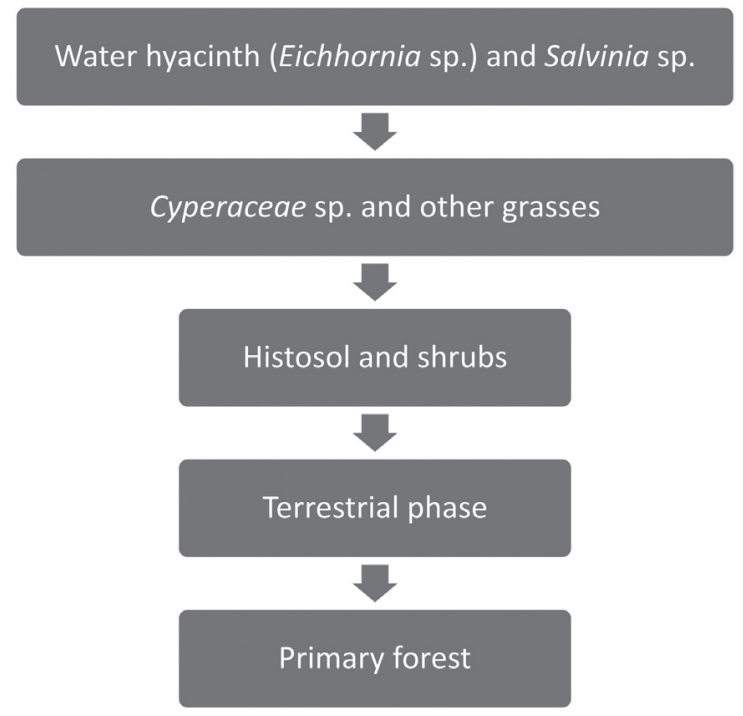

Figure 8 - Conceptual model of formation of terrestrial vegetation areas in wetlands, particularly in distal fluvial megafans

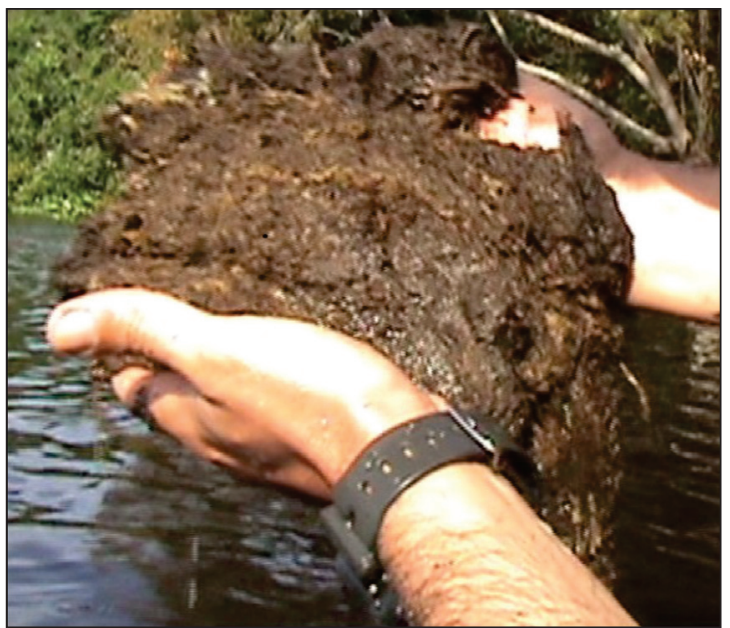

Figure 9 - Video frame of histosol collected from the Paraguay River near Forte Coimbra. When the video was recorded in June 2011, the Paraguay

River flood reached a maximum stage of $554 \mathrm{~cm}$ at the Ladário, MS

gauge. During large annual floods when baceiros break away

from abandoned meanders and lakes, the baceiros can be collected along the main trunk of the Paraguay River.

These histosols found along the river are locally known as 'batumes' among the pantaneiros 
In the context of Riverine Ecosystem Synthesis (RES), watersheds contain Functional Process Zones (FPZs). The RES is a concept that incorporates ecological succession with the evolution of river-dominated ecosystems (THORP et al., 2006, p.123). In the concept of the River Continuum, the characterization of a FPZ from the source to the mouth of a drainage basin accounts for specific local differences in discharge and sedimentation rates, climate, depth, and present species (VANNOTE et al., 1980, p.131; THORP et al., 2006, p.128). Generally, FPZs have distinct functions and are controlled by scale, so the surroundings of Lake Uberaba on the fringes of the Paraguay River fluvial fan constitute a type of FPZ that should be naturally replicated in other fluvial fans of the Pantanal and other wetland analogs. In terms of the aquaticterrestrial ecological succession model (Figure 8), the FPZs can evolve to become other FPZs as a function of avulsive processes, such as those that occur in the Pantanal (ASSINE et al., 2015a, p.107).

\section{CONCLUSIONS}

The role of floating aquatic macrophytes in open water reduction in Lake Uberaba was verified with the use of Landsat series historic images. Over approximately three decades, the area of the lake diminished $\sim 21.4 \%$. Considering the possibility of aquaticterrestrial ecological succession, the lake can radically change its configuration over time. Terrestrial areas will increasingly be dominated by woody vegetation composed of $k$-strategists growing on histosols.

The hypothesis of aquatic-terrestrial ecological succession in fluvial distributary systems described in this study can help improve the description and understanding of dynamic processes acting in tropical floodplain lakes in wetlands. New studies that confirm, refute, or improve this model will be necessary to better understand ecosystem evolution using new fieldwork and satellite (e.g., Synthetic Aperture Radar) images with better spatial and spectral resolution.

Multidisciplinary studies help clarify issues about the dynamic geomorphic processes acting on the Pantanal floodplain. The results and premises developed herein increase the understanding of the role of aquatic macrophytes as geomorphic agents in the Pantanal floodplain, influencing the trophic level, formation, and longevity of alluvial floodplain lakes. Geo-ecological studies at various time scales linked to hydrologic changes should also contribute to a greater understanding of the evolution of the Pantanal as a natural system.

\section{ACKNOWLEDGMENTS}

The authors thank Jocemir Antunes and ECOA for logistical support. Commissão Fulbright Brasil along with CAPES financed this study in Corumbá for E.L.L. and helped partner North American and Brazilian researchers. This study had additional institutional support from Embrapa-Pantanal, the Federal University of Mato Grosso do Sul-Pantanal Campus, and UNESP-Rio Claro on FAPESP project 2014/06889-2 (Quaternary paleohydrologic changes, chronology, and sedimentary dynamics of the Pantanal Basin). The Foundation for Support of Teaching, Science, and Technology of the state of Mato Grosso do Sul - FUNDECT (Termo de Outorga 083/2016) and the National Council of 
Scientific and Technological Development - CNPq (processes 447402/2014-5 and 448923/2014-9) were important funders. A research grant (PQ2) awarded to A.S. (312.386/2014-1) is greatly appreciated. The authors also thank the $17^{\text {th }}$ Brazilian Army Border Battalion-Corumbá for fieldwork support.

\section{REFERENCES}

ALMEIDA, T. I. R.; SÍGOLO, J. B.; FERNANDES, E.; QUEIROZ NETO, J. P.; BARBIERO, L.; SAKAMOTO, A. Y. Proposta de Classificação e Gênese das Lagoas da Baixa Nhecolândia-MS com Base em Sensoriamento Remoto e Dados de Campo. Revista Brasileira de Geociências, v. 33, n. 2, p. 83-90, 2003.

AMOROS, C.; BORNETTE, G. Connectivity and biocomplexity in waterbodies of riverine floodplains. Freshwater Biology, v. 47, n. 4, p. 761-776, 2002.

ANDERSON, D. H. Geomorphic Responses to Interim Hydrology Following Phase I of the Kissimmee River Restoration Project, Florida. Restoration Ecology, v. 22, n. 3, p. 367-375, 2014.

ASSine, M. L.; MACEDO, H. A.; STEVAUX, J. C.; BeRgIER, I.; PADOVANI, C. R.; SILVA, A. Avulsive Rivers in the Hydrology of the Pantanal Wetland. In: BERGIER, I.; ASSINE, M. L. (Ed.). Dynamics of the Pantanal Wetland in South America, New York: Springer, 2015a. Ch. 4, p. 83-110.

ASSINE, M. L.; MERINO, E.R.; PUPIM, F. N.; MACEDO, H. A.; SANTOS, M. G. M. The Quaternary alluvial systems tract of the Pantanal Basin, Brazil. Brazilian Journal of Geology, v. 45, n. 3, p. 475-489, 2015b.

ASSINE, M. L.; SILVA, A. Contrasting fluvial styles of the Paraguay River in the northwestern border of the Pantanal wetland, Brazil. Geomorphology, v. 113, n. 3, p. 189-199, 2009.

ASSINE, M. L.; SOARES, P. C. Quaternary of the Pantanal, west-central Brazil. Quaternary International, v. 114, n. 1, p. 23-34, 2004.

AYACH, L. R.; BACANI, V. M.; SILVA, J. F. Unidades de Conservação no Pantanal do município de Aquidauana-MS: uma análise da evolução do uso da terra e cobertura vegetal e suas implicações. Caderno de Geografia, v. 24, n. 42, p. 138-154, 2014.

BERGIER, I.; RESENDE, E. K. Dinâmica de cheias no Pantanal do rio Paraguai de 1900 a 2009. In: SIMPÓSIO DE GEOTECNOLOGIAS NO PANTANAL, 3., Cáceres, MT, Brazil, 16-20 October 2010. Anais... Campinas: Embrapa Informática Agropecuária; São José dos Campos: INPE, 2010. p. 35-43.

CAI, L. N.; TANG, D. L.; LI, C. Y. An investigation of spatial variation of suspended sediment concentration induced by a bay bridge based on Landsat TM and OLI data. Advances in Space Research, v. 56, n. 2, p. 293-303, 2015.

CASTRO, W. J. P.; VIANNA, E. F.; SALIS, S. M.; GALVANI, F.; LIMA, I. B. T. Composição Florística e Fauna Associada das Ilhas Flutuantes Livres, Rio Paraguai, Corumbá, MS. In: SIMPÓSIO SOBRE RECURSOS NATURAIS E SOCIOECONÔMICOS DO PANTANAL, 5., Corumbá, MS, Brazil, 9-12 November 2010. Anais... Corumbá Embrapa, 2010. $4 \mathrm{p}$.

COHEN, A. S. Paleolimnology: The History and Evolution of Lake Systems. New York, Oxford University Press, 2003. 525 p. 
COHEN, A. S.; MCGLUE, M. M.; ELLIS, G. S.; ZANI, H.; SWARZENSKI, P. W.; ASSINE, M. L.; SILVA, A. Lake formation, characteristics, and evolution in retroarc deposystems: A synthesis of the modern Andean orogeny and its associated basins. In: DECELLES, P. G.; DUCEA, M. N., CARRAPA, B.; KAPP, P. A. (Ed.). Geodynamics of a Cordilleran Orogenic System: The Central Andes of Argentina and Northern Chile, Boulder, CO: Geological Society of America Memoir 212, 2015. Ch. 16, p. 309-335.

COPATTI, A.; DALMAS, F. B.; OlIVEIRA, A. P. G.; RIBEIRO, A.; PARANHOS FILHO, A. C. Uso de Geotecnologia Livre na Avaliação das Mudanças na Cobertura Vegetal e da Zona de Amortecimento do Parque Estadual do Pantanal do Rio Negro, Mato Grosso do Sul. Anuário do Instituto de Geociências-UFRJ, v. 38, n. 2, p. 37-46, 2015.

GADGIL, M.; SOLBRIG, O. T. The Concept of $r$ - and k-Selection: Evidence from Wild Flowers and Some Theoretical Considerations. The American Naturalist, v. 106, n. 947, p. 14-31, 1972.

GALO, M. L. B. T.; Velini, E. D.; TRINIDADE, M. L. B.; SANTOS, S. C. A. Uso do Sensoriamento Remoto Orbital no Monitoramento da Dispersão de Macrófitas nos Reservatórios do Complexo Tietê. Planta Daninha, v. 20, p. 7-20, 2002.

HEILER, G.; HEIN, T.; SCHIEMER, F.; BORNETTE, G. Hydrological connectivity and flood pulses as the central aspects for the integrity of a river-floodplain system. Regulated Rivers: Research and Management, v. 11, n. 3-4, p. 351-361, 1995.

LATRUBESSE, E. M. Large rivers, megafans and other Quaternary avulsive fluvial systems: A potential "who's who" in the geological record. Earth-Science Reviews, v. 146, p. 1-30, 2015.

LEIER, A. L.; DECELles, P. G.; PELleTIER, J. D. Mountains, monsoons, and megafans. Geology, v. 33, n. 4, p. 289-292, 2005.

MCGLUE, M. M.; SILVA, A.; ASSINE, M. L.; STEVAUX, J. C.; PUPIM, F. N. Paleolimnology in the Pantanal: using lake sediments to track quaternary environmental change in the world's largest tropical wetland. In: BERGIER, I.; ASSINE, M. L. (Ed.). Dynamics of the Pantanal Wetland in South America, New York: Springer, 2015. Ch. 3, p. 51-81.

MIN, J. E.; RYU, J. H.; LEE, S.; SON, S. H. Monitoring of suspended sediment variation using Landsat and MODIS in the Saemangeum coastal area of Korea. Marine Pollution Bulletin, v. 64, p. 382-390, 2012.

MORAES, L. A. F. A visão integrada da ecohidrologia para o manejo sustentável dos ecossistemos aquáticos. Oecologia Brasiliensis, v. 13, n. 4, p. 676-687, 2009.

PALÁCIOS, R. S.; SALLO, F. S.; MARQUES; J. B.; MENEZES; J. A.; NOGUEIRA, J. S. Variabilidade da Profundidade Ótica de Aerossóis Atmosféricos sobre o Pantanal Brasileiro. Revista Brasileira de Climatologia, v. 18, p. 27-37, 2016.

PEREIRA, L. E.; LASTORIA, G.; ALMEIDA, B. S.; HAUPENTHAL, M.; JÚNIOR, J. M.; LO, E. L.; PARANHOS FILHO, A. C. Application of aerial photographs and orbital sensors to identify and delineate water bodies. Boletim de Ciências Geodésicas, in press, 2017.

PIVARI, M. O.; POTT, V. J.; POTT, A. Macrófitas aquáticas de ilhas flutuantes (baceiros) nas sub-regiões do Abobral e Miranda, Pantanal, MS, Brasil. Acta Botanica Brasilica, v. 22, n. 2, p. 563-571, 2008.

POTT, A.; SILVA, J. S. V. Terrestrial and Aquatic Vegetation Diversity of the Pantanal Wetland. In: BERGIER, I.; ASSINE, M. L. (Ed.). Dynamics of the Pantanal Wetland in South America, New York: Springer, 2015. Ch. 5, p. 111-131. 
SOUZA, R. C. S.; VIANNA, E. F.; PELlEGRin, L. A.; SALIS, S. M.; COSTA, M.; BeRGIER, I. Localização de áreas permanentes de vegetação aquática na planície de inundação do Rio Paraguai e adjacências. In: SIMPÓSIO BRASILEIRO DE SENSORIAMENTO REMOTO, 15., Curitiba, PR, Brazil, 30 April-5 May 2009. Anais... São José dos Campos: INPE, 2011. p. 2036-2043.

THORP, J. H.; THOMS, M. C.; DELONG, M. D. The Riverine Ecosystem Synthesis: Biocomplexity in River Networks Across Space and Time. River Research and Applications, v. 22, n. 2, p. 123-147, 2006.

VANNOTE, R. L.; MINSHALL, G. W.; CUMMINS, K. W.; SEDELL, J. R.; CUSHING, C. E. The River Continuum Concept. Canadian Journal of Fisheries and Aquatic Sciences, v. 37, n. 1, p. 130-137, 1980.

WARD, J. V.; TOCKNER, K.; SCHIEMER, F. Biodiversity of floodplain river ecosystems: ecotones and connectivity. Regulated Rivers: Research and Management, v. 15, n. 1-3, p. 125-139, 1999.

WEISSMANN, G. S.; HARTLEY, A. J.; NICHOLS, G. J.; SCUDERI, L.A., OLSON, M.; BUEHLER, H.; BANTEAH, R. Fluvial form in modern continental sedimentary basins: Distributive fluvial systems. Geology, v. 38, n. 1, p. 39-42, 2010.

WOODCOCK, C. E.; ALLEN, R.; ANDERSON, M.; BELWARD, A.; BINDSCHADLER, R.; COHEN, W.; GAO, F.; GOWARD, S. N.; HELDER, D.; HELMER, E.; NEMANI, R.; OREOPOULOS, L.; SCHOTT, J.; THENKABAIL, P. S.; VERMOTE, E. F.; VOGELMANN, J.; WULDER, M. A.; WYNNE, R. Free access to Landsat imagery. Science, v. 320, n. 5879, p. $1011-1011,2008$. 